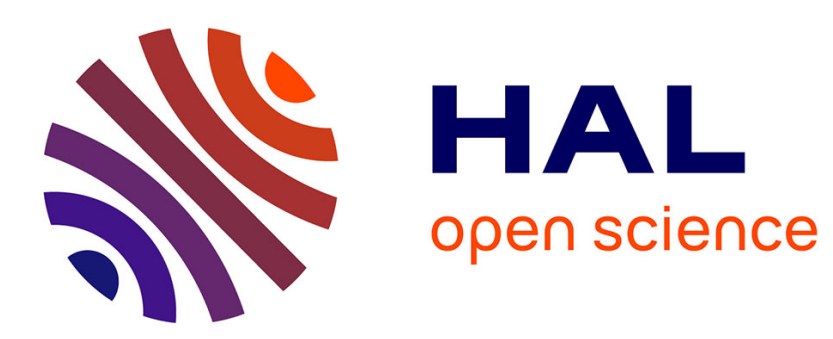

\title{
The Evolution of Public Service Provision by the Third Sector in France
}

Edith Archambault

\section{To cite this version:}

Edith Archambault. The Evolution of Public Service Provision by the Third Sector in France. Political Quarterly, 2017, 88 (3), pp.465-472. 10.1111/1467-923X.12393 . halshs-01598959

\section{HAL Id: halshs-01598959 \\ https://shs.hal.science/halshs-01598959}

Submitted on 30 Sep 2017

HAL is a multi-disciplinary open access archive for the deposit and dissemination of scientific research documents, whether they are published or not. The documents may come from teaching and research institutions in France or abroad, or from public or private research centers.
L'archive ouverte pluridisciplinaire HAL, est destinée au dépôt et à la diffusion de documents scientifiques de niveau recherche, publiés ou non, émanant des établissements d'enseignement et de recherche français ou étrangers, des laboratoires publics ou privés. 


\title{
The evolution of public service provision by the third sector in France
}

\author{
Edith Archambault, \\ Centre d'économie de la Sorbonne, Université Paris 1 Panthéon-Sorbonne
}

\section{Introduction}

In France as in the United Kingdom, government functions have been partly externalised to the third sector, while public authorities continue to provide the bulk of their funding. Health, education and social services were the first to be affected by this trend. These welfare state functions are examined here, even if externalisation has also been extended to the sovereign functions of government during the last decade. The latter include notably justice services such as alternatives to imprisonment, as well as the implication of associations in preventing and following up delinquency.

The financial crisis which began in 2007 lead both the UK and France to pursue policies supporting the financial sector along with Keynesian fiscal stimuli is in 2008-2009, which deepened public deficits and increased public debt. In 2010, the United Kingdom and a little later France shifted towards austerity policies. These led to budget cuts that have impacted the third sectors in both countries.

The theory of social origins, drawing on the work of Esping-Andersen and others, identifies four models for the development of the non-profit sector which are characterised by their relationship to government and to different social forces. These include social class relations, the diversity and power of religions, and the social insurance system among other factors. This theory has been tested using the results of the second phase of the Johns Hopkins Comparative Nonprofit Project, which relates to about 40 countries at various levels of development and from different cultural spheres. These four models are summarised in Table 1, which crosses the relative importance of public social spending and the size of the third sector. ${ }^{\mathrm{i}}$

Table 1. Models of the Third Sector

\begin{tabular}{|c|c|c|}
\hline $\begin{array}{l}\text { Public social spending as a \% } \\
\text { of GDP }\end{array}$ & \multicolumn{2}{|c|}{$\begin{array}{c}\text { Size of the third sector } \\
\text { (employment of the third sector / total employment) }\end{array}$} \\
\hline Weak & Restricted & Significant \\
\hline High & $\begin{array}{c}\text { Statist } \\
\text { Liberal } \\
\text { Eastern Europe) }\end{array}$ & $\begin{array}{c}\text { Latin America, } \\
\text { (English-speaking countries) }\end{array}$ \\
& $\begin{array}{c}\text { Social Democrat } \\
\text { (Nordic countries) }\end{array}$ & $\begin{array}{c}\text { Corporatist } \\
\text { (Germany, Austria, } \\
\text { Netherlands, Belgium, } \\
\text { France, Italy) }\end{array}$ \\
\hline
\end{tabular}

In the liberal model, there is a large non-profit sector (accounting for 8-10\% of all employment) which coexists with low public social spending. This in turn translates longterm political and ideological hostility by the middle-class to the extension of a public welfare state, as shown by the protracted resistance to Obamacare in United States for example. This same middle-class however claims and supports the non-profit sector. So there is clearly 
competition between the two sectors: as the welfare state grows, it pushes out the non-profit sector, whereas when the welfare state shrinks, the third sector tries to fill the void and meet unsatisfied social needs.

By contrast, in the corporatist model there is more complementarity between a high level of welfare spending and a large non-profit sector (7-12\% of total employment). Government continues to define social policy, but delegates part of its implementation to organisations which are closer to users. A large share of the finance going to non-profit health and social organisations comes from the contributory social security system which preserves the hierarchy of social classes. Education on the other hand is largely financed by central and local government, to various degrees, depending on the extent of devolved power.

According to social origins theory, the French and British non-profit sectors belong to different models. The United Kingdom shares the liberal model which is common to the English-speaking countries, and in which public authorities and the third sector are rivals. In contrast, the continental countries of Western Europe follow a corporatist model, grounded in fundamental partnership. However the exact relationship to public authorities in both countries is shaped by contrasting historical traditions, which have varied over time.

There are however significant differences between countries which logically belong to the same regime, following from different historical and political traditions. In particular, countries may import social innovations from their neighbours and the European Union favours the adoption of best practices. This has led to hybrids between the different models of the third sector. From this point of view, neither United Kingdom nor France can claim to be ideal types in terms of the liberal and corporatist models. The former began with a strong welfare state set up under Beveridge, but which has been partially and unequally eroded since the Thatcher years. For its part, France began with a strong statist model, but over time this has shifted little by little to a high degree of partnership. ${ }^{\text {ii }}$

This article mainly looks at the French case, even if some short references are made to the UK. It starts with an inventory of relations between the public sector and the non-profit sector, before 2008. This is followed by a description of changes since then, marked by the slow reduction of public financing and by adaptation strategies on behalf of non-profit organisations as well as companies operating in welfare state services. These are mainly education, health and social services, all of which are at the heart of partnership relations. The conclusion reviews some historical conditions and diverse policies that have led to this welfare-mix.qui devrait se renforcer avec l'application progressive de la loi du 31 juillet 2014 relative à l'économie sociale et solidaire ${ }^{\text {iii }}$

Cette loi, en effet, définit l'économie sociale solidaire (ESS) comme l'ensemble des coopératives, des mutuelles, des associations, des fondations et des entreprises de droit commun à but social ou environnemental respectant un certain nombre de règles. Favorable à la diversité des formes d'entreprise, la loi encourage un changement d'échelle de l'ESS, et fonde une stratégie de croissance inclusive. Elle renforce le financement des associations, donne plus de pouvoir aux salariés et soutient le développement durable local.

Il est évidemment trop tôt pour évaluer les conséquences de cette loi dont les décrets d'application ont été promulgués en 2015, mais cette loi consacre et renforce une évolution spontanée et un partage des service publics déjà lergement amorçé. 


\section{A brief history of relations between the public sector and the third sector in France}

France's third sector is more recent than its British counterpart, because it was repressed after the Revolution and throughout the 19th century. It has however developed rapidly as of the 1960 s, and is strongly concentrated in sectors shared with the State (l'Etat or France's central government). These include social services, education and health, where services are organised in partnership with non-profits or associations managing services and central government providing finance, often entirely. France's foundations are still recent. There are few of them and they are not very powerful compared to British foundations.

France's devolution laws (lois de décentralisation) of 1983 and 2003 boosted growth of the third sector. They gave new competencies to local government in health, social services and vocational training. These new functions have been partially externalised towards non-profits which already existed locally. The organisations that manage new services which are financed through subsidies or contracts with regional government, departments (roughly similar to counties) and communes. More recently, the Law of 2003 relaxed the legal regime for foundations and diversified their forms. Subsequently, the Law of 2009 created endowment funds, inspired by the British model. Since then, the number of foundations has grown rapidly, allowing France to catch up partly with other European countries.

The financial crisis which spilled over from the United States and the sovereign debt and Euro crises have led to a fall in public financing of non-profits. This has weakened them precisely at the moment when they are providing social and humanitarian services which are strongly in demand, given the newly-impoverished populations that have resulted from the economic crisis and long-term unemployment. As in the UK, the crisis led to large public finance deficits. To cut these deficits, France's central government has reduced subsidies to partner associations, more than its contracts, while enhancing public procurement. These cuts in central government financing were initially compensated by local government. However, when the latter began to experience significant deficits in their turn, in 2011, local financing was reduced as well. ${ }^{\text {iv }}$

The cuts in public financing have been accompanied by changes in its format, which has destabilised non-profits: subsidies have been strongly reduced in favour of public contracts with competitive tenders, again inspired by the British example. As a result, non-profits have found themselves in competition with private companies, and also in competition with each other. Many of the smallest nonprofits have not been able to enter such competition due to a lack of qualified staff needed to fill out official forms correctly, and many have therefore closed. Foundations which are less dependent on public money have not experienced the same financial difficulties: their staff have increased more rapidly than their spending, and in 2009 they even benefited from the tax exemption of donations they received from the wealthiest French citizens who are subject to France's wealth tax. ${ }^{\mathrm{V}}$

Faced with these changes, non-profits have sought to diversify their funding sources, by raising more donations, although here too competition has proved tough. Organisations which do not directly cater for disadvantaged groups have increased their use of fees. Public financing has also been diversified. Vouchers have been used to make demand solvent: the personalised autonomy allowance (allocation personnalisée d'autonomie) for dependent older people and the disability compensation allowance (allocation de compensation du handicap) are only used to pay for personal social services at home or in residential care. Tax exemptions for donors have been increased in order to diversify the resources of the third 
sector. Moreover, many subsidised jobs and a civic service for young people who are strongly marginalised from the labour market have been created and financed by the State to bring down mass unemployment: non-profits have been by far the largest employer of these young people.

Finally, in these difficult times, the grounding of associations and foundations within a broader social and solidarity economy, which also includes cooperatives and mutual insurance societies, has been consolidated. The social and solidarity economy was defined, enhanced and written into the Law of July 2014. ${ }^{\text {vi }}$ Since this law, subsidies have been restored and have finally been clearly defined. Public/third sector partnerships have also been renewed, while local authorities have now introduced social clauses in public markets which de facto favour the third sector. This is a change from previous practices that based public procurement solely on the basis of lowest prices, in order to ward off any suspicion of clientelism. Very recently, there has been greater recourse to non-profits to manage numerous services for persons in great difficulty (refugees, the homeless, drug addicts, etc.). For such services, public authorities provide initial investments and cover some running costs.

\section{Today's third sector and the sharing of public services between the three sectors}

The French third sector is made up mostly of associations or societies which have a very flexible status governed by the Law of 1901. This century-old law provides a framework in which several associates may pursue any particular goal other than sharing profits, in other words pursue a common or general interest. France's third sector therefore also includes a minority of foundations and other non-profit organisations, such as political parties, unions and religious organisations. France's major foundations operate services, such as the Rothschild foundation or the French Health Foundation for Students which manage hospitals, or the Fondation d'Auteuil that is responsible for educating and training children whose parents have lost their custody. The importance of grant-making foundations is more limited, the most important being the Fondation de France, which was created in 1969 at the initiative of the French State.

There are about 1,300,000 active non-profits in France, and only 2,230 foundations, despite recent growth. Most non-profits or associations (88\%) are very small, voluntary organisations. They have no employees and operate in all areas, though principally in sports, culture, and leisure activities, as well as the defence of rights and causes. Their main resources come from revenues linked to their activities and the contributions of their members. Some symbolic local public finance may be added to such private funding. ${ }^{\text {vii }}$

Only about 160,000 non-profits employ staff, though their economic weight is much greater. This figure can be compared with the 183,000 charities listed by the Charity Commission in England and Wales. As with private companies, a very large majority of non-profits are small organisations, and more than half which do have paid staff only employ one or two persons. However, $11 \%$ of non-profits do indeed employ more than 20 people. These are large organisations operating mainly in traditional public services such as education, health and social services, and which are involved in partnerships.

In 2014, France's non-profits employed 1,928,000 persons $(1,845,000$ for non-profits and 83,000 for foundations). As non-profits usually have more part-time staff than do private companies or public organisations, it is preferable to look at figures for full-time equivalent staff. Accordingly, total employment in the sector was 1,618,000 full-time equivalent in 2014, 
accounting for $7.5 \%$ of all paid jobs. Between 1990 and 2014, employment in the non-profit sector doubled, whereas overall employment in the economy only expanded by $15 \%$.

The total resources of France's non-profit sector in 2013 amounted to $€ 104$ billion, similar in magnitude to England and Wales ( $£ 71$ billion) ${ }^{\text {viii }}$. But such comparison comes with some methodological qualification:; parce que le perimeter des associations et des charities n'est pas le même et quelques employeurs non lucratifs britanniques importants ne sont pas des charities $^{\mathrm{ix}}$. It should be noted that the British sector is less dependent than its French counterpart on public funding, and draws more on marketing resources and private donations.

The traditional activities of the welfare state such as education, health and social services, account for $75 \%$ of total third sector employment. This supports the idea that France has clearly entered the era of a welfare mix, along the lines of most continental European countries, as shown in Table 2. Social services alone account for more than half of all employment in the non-profit sector. They include residential facilities and day care, as well as home care for the elderly, the disabled, emergency support and help with social distress, crèches and other structures for children and adolescents, as well as family counselling services and back-to-work assistance.

Table 2: The breakdown of paid employment in public services across the private, nonprofit and public sectors, in 2011

\begin{tabular}{|l|c|c|c|c|}
\hline \multirow{2}{*}{ Area } & \multicolumn{2}{|c|}{ Employment share by sector } & \multirow{2}{*}{ TOTAL } \\
\cline { 2 - 4 } & $\begin{array}{l}\text { Private non- } \\
\text { profit }\end{array}$ & $\begin{array}{l}\text { Private for- } \\
\text { profit }\end{array}$ & Public & \\
\hline Education & $19 \%$ & $5 \%$ & $76 \%$ & $100 \%$ \\
\hline Health & $12 \%$ & $23 \%$ & $65 \%$ & $100 \%$ \\
\hline Social services & $62 \%$ & $10 \%$ & $28 \%$ & $100 \%$ \\
\hline $\begin{array}{l}\text { Share of total } \\
\text { employment in } \\
\text { France }\end{array}$ & $\mathbf{7 . 5 \%}$ & $\mathbf{6 7 \%}$ & $\mathbf{2 5 . 5 \%}$ & $\mathbf{1 0 0 \%}$ \\
\hline
\end{tabular}

Sources $^{x}$

Table 2 shows the variety of the welfare mix according to the main areas of welfare policy. In terms of education, the public sector accounts for the lion's share of jobs. The presence of private companies is recent and is mainly limited to private tutoring and "cramming" services for students preparing competitive exams to enter certain establishments in France's higher education system. That said, the non-profit sector provides schooling for one fifth of all pupils in primary and secondary schools, $90 \%$ of which are Catholic schools. These establishments operate under contract with the State, have the same curriculums as State schools and accept children of all religions. But they have a bit more pedagogical freedom, and more discretion in choosing teachers. The State recruits and pays their teachers, while local government maintains their premises. As a result, fees in this private non-profit sector are usually low. In higher education, aside five small Catholic universities, the non-profit sector runs business schools, as well as some of the training for nurses and social workers. Most higher education is therefore public, and practically free, as enrolment fees are very low and have not increased, despite the greater autonomy of universities. Lifelong vocational learning is provided by non-profit organisations and private companies, and is financed through a special type of business tax. 
The provision of health services is spread much more evenly between private companies, non-profits and public institutions, even more so than indicated in Table 2, which only includes paid jobs. An important part of the for-profit services are provided by self-employed workers, including doctors, nurses, and paramedics who are essentially operating in a free market. The private for-profit sector is therefore understated, whereas the public sector mainly hospitals - is overstated. This mixed health system is clearly very different to the British NHS, which has remained predominantly public despite waves of privatisation that have reduced the State's monopoly. France's health services get $76.5 \%$ of their finances through the public health insurance system, $1.5 \%$ from the State covering the most deprived patients, and $13.5 \%$ from complmentary health insurance (non-profit mutual insurance societies or private insurance companies). Finally, $8.5 \%$ of financing comes from out-ofpocket fees paid by patients, a share which is more important in the private commercial health sector than in the public or non-profit sectors. Out-of-pocket payments by patients and the share of complimentary health insurance have grown during the last decade, as the share of public financing has diminished in order to balance the accounts of France's public health system. ${ }^{\mathrm{xi}}$

Employment and social services are predominantly in the non-profit sector, with more than $6 / 10$ social service workers being employed by associations or foundations. The non-profit sector even has a virtual monopoly for residential establishments and assistance at work for people with disabilities. The penetration of private companies in this field is recent and mainly concerns retirement homes and other establishments for the elderly: major hotel chains have recently started diversifying into this sector which is forecast to grow strongly. The public sector is also very present for establishments and services for the elderly, though its share is declining. The public sector also runs the majority of institutions and services looking after children under three years old in crèches. But, associative non-profit and company crèches also exist. For children aged 3 to 6 , after which schooling is obligatory, public kindergartens cater to nearly all children. Finally, social services for home help are largely provided by non-profit associations. However, since the Borloo Law of 2005 which provides the elderly and disabled with vouchers (the job-service cheque, i.e. chèque emploi service) this near monopoly is being eroded, as private companies have entered the market significantly, cream skinning certain activities like retirement homes for clients with high incomes.

\section{The value-added of voluntary work in the third sector}

Table 2 is based on the most reliable statistical data, namely wage employment. But this underestimates the impact of the non-profit sector by neglecting its specific contribution in terms of voluntary work. This remains the dominant and oldest characteristic of British voluntary organisations, and is rooted in British culture, as citizens do voluntary work from school onwards in Great Britain and not in France. The Charity Commission estimates that there are 3,456,000 regular voluntary workers in charities in England and Wales. A further 944,000 trustees can be added to this, carrying out collectively various types of management functions on a voluntary basis.

Figures concerning voluntary work are far scarcer in France and are surely not comparable. ${ }^{\text {xii }}$ Drawing on these scarce sources, there seem to be 16 million voluntary workers, operating alone or alongside salaried employees. These volunteers are usually occasional contributors, working in organisations of general interest; some 3 million are regular volunteers Over the 
last 20 years, statistics indicate that the number of voluntary workers has doubled and that the rate of voluntary work has risen continuously, rising from $19 \%$ of the adult population in 1990 to $32 \%$ in 2010. When converted into full-time equivalent employment, voluntary labour time exceeds one million jobs according to Tchernonog, although INSEE (France's National Institute of Statistics and Economic Studies) calculates an equivalent of only 680,000 jobs. Three quarters of the time dedicated by voluntary workers is given to nonprofits with no salaried staff, and such associations would disappear without this voluntary support. One quarter of voluntary work goes to organisations with employees, but where volunteers usually carry out different functions to paid employees. More than two thirds of voluntary labour time is dedicated to managing and organising cultural, sports and leisure activities, but also to defending rights, interests and causes. However, the annual time given by most voluntary workers is longer in social, charity and health services provided by nonprofit organisations.

Voluntary work is clearly a specificity of the third sector and is also a means for identifying it statistically or for tax purposes. Such work also provides value-added with respect to the carrying out of educational health and social services by public authorities, as volunteers' work is often characterised by more humanity and personalisation. It should also be added that the creation of non-profits and foundations is done on a voluntary basis and that leading administrative functions of executive bureaus and/or boards are carried out on a voluntary basis, depending on the size of the organisation.

\section{Conclusion}

The sharing of educational, health and social services between the State (France's central government), local government and the third sector obviously depends on functions that have been devolved to local government as well as on the level of externalisation or subcontracting which public authorities consider to be relevant. Recourse to the voluntary sector makes it possible to stabilise or reduce public employment, which is very high in France, and so increases voluntary value-added. Moreover, innovation and experimenting in social policies is easier in the third sector, given the principle of equal treatment which prevails in public services and which makes experimenting more difficult within the public sector. For the same reason, the third sector also adapts itself more easily than the public sector to diversity across France's regions and populations. For its part, the public sector guarantees universal access to services provided and the equal treatment of all users. The public sector also largely retains responsibility for sovereign functions relating to the justice system, as well as internal and external security. Various types of partnership contracting between the public and non-profit sectors makes it possible to combine the advantages of both, while imposing regulation on the access to services and their permanence, in exchange for partial or almost total public financing of non-profit organisations.

The split between public authorities and the non-profit sector also depends strongly on the legacy of history, as well as on conflicts that have occurred over centuries. For example, the relatively weak penetration of the non-profit sector into France's education system, when compared to neighbouring countries like Belgium, the Netherlands or Italy, follows from the historical conflict between the Catholic Church and the French State in the wake of the French Revolution in 1789 right through to the compromise Laws of Barangé and Debré in the 1960s. These laws implemented the existing partnership, which is still contested by the most secular fringe of France's political spectrum. 
The split between public and non-profit organisations also depends on particular initiatives, and which sector was first responsible for identifying specific needs. In the area of social work, non-profits often took the initiative to meet new needs or provide services to very varied populations. Services to the disabled are an emblematic example: after World War I, the State largely took responsibility for wounded and maimed soldiers, whereas disabled civilians remained predominantly dependent on their families. Families then came together in associations for supporting physically disabled persons Between the Wars, and for persons with mental disabilities after 1950. These organisations defended the rights of disabled persons and offered non-residential services and sometimes residential care. In the 1960s, partnerships with the State made it possible for such non-profits to increase services considerably, as public funding became almost total. Today, we can see a similar application of the principle of subsidiarity for the accommodation of homeless persons or the reception of refugees.

Associations are presently dynamic institutions in France which are much appreciated by the public, whereas political institutions, unions and religious organisations are subject to mistrust or indifference. Foundations, after being discredited for a long time, have experienced spectacular growth since 2003. The third sector is therefore currently looking for its place in the public sphere, either in close partnership with public authorities, or within the social and solidarity economy. La loi ESS de .2014 veut accélérer d'une part le dynamisme des organisations de l'ESS et d'autre part leur faire prendre conscience de leur unité et de leur poids politique et on en voit actuellement les prémisses en dépit de la rupture de croissance provoquée par la crise de 2008 .

The impact of the 2008 financial crisis led to employment in the third sector falling for the first time in 2011. More recently the impact has diminished and employment is again increasing, though at a much slower rate than before 2008. Faced with financial difficulties, some organisations have merged with others in the same area of activity or geographic zone. Other, much more numerous organisations are now sharing premises, infrastructure, equipment and facilities as well as qualified personnel. France's associations are surely too small and too numerous when compared to their counterparts in other countries, and the concentration of the sector is undoubtedly only in its first stages. It will likely strengthen in the future, as foreseen by the Law on the social and solidarity economy of 2014 qui facilite les fusions et autres restructurations d'associations. There is no doubt that associations which have already demonstrated resilience and ingenuity will be able to adapt to this new environment which is more unfavourable to them. Foundations disbursing funds, which have finally become more visible in France, should help with this restructuring of associations, as should cooperative banks and public authorities as they cannot turn away from these auxiliary providers of public services. 


\section{References}

${ }^{\mathrm{i}}$ Salamon, Lester \& Anheier, Helmut (1998). Social origins of civil society: Explaining the
nonprofit sector cross-nationally. Voluntas: International journal of voluntary and nonprofit
organizations, 9(3), 213-248
Salamon, Lester; Anheier, Helmut ; List, Regina ; Toepler, Stefan ; Sokolowski, Wojcieck (1999). Global civil
society. Dimensions of the Nonprofit sector. Baltimore

Esping-Andersen, Gosta (1990) The three worlds of Welfare Capitalism, Princeton, Princeton University Press

ii Archambault, Edith. (2001). Historical roots of the nonprofit sector in France. Nonprofit and Voluntary Sector Quarterly 30.2 : 204-220.

Rosanvallon, Pierre (2007) Le modèle politique français. La société civile contre le jacobinisme de 1789 à nos jours. Paris, Seuil.

iii LOI n 2014-856 du 31 juillet 2014 relative à l'économie sociale et solidaire

iv Tchernonog, Viviane (2013), Le paysage associatif français. Mesures et évolution, Paris, Juris-éditions et Dalloz.

Archambault Edith (2015) France: A Late-Comer to Government-Nonprofit Partnership in Lester Salamon Edr, Unlikely Partners? Evolving Government-Nonprofit Relationships, East and West, numéro special de Voluntas: International journal of voluntary and nonprofit organizations, 26-6, 2283-2310

${ }^{\mathrm{v}}$ Archambault, Edith, Eckhart Priller, and Annette Zimmer (2014) European Civil Societies Compared: Typically German-Typically French?. Voluntas 25-2: 514-537

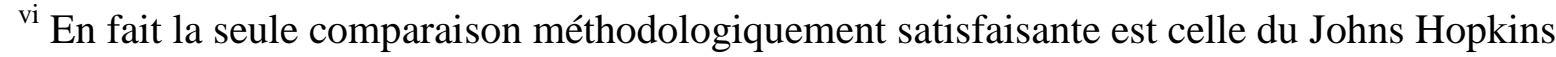
Comparative Program of the Nonprofit sector, évoqué dans la note 1

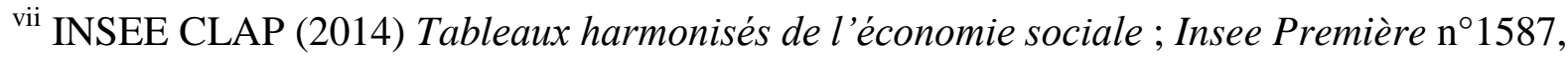
mars 2016

CNCRES, Observatoire national de l'ESS (2014) Atlas commenté de l'économie sociale et solidaire, Paris, Juris-éditions et Dalloz

viii https://data.ncvo.org.uk/a/almanac16/income-from-government

https://data.ncvo.org.uk/a/almanac16/fast-facts-5/

INSEE Première. Neuf associations sur dix fonctionnent sans salariés n ${ }^{\circ}$ 1587, mars 2016

INSEE Résultats : https://www.insee.fr/fr/statistiques/2106164?sommaire=2106166

ix

${ }^{\mathrm{x}}$ Observatoire de la Fondation de France (2015) Etude fonds et fondations 2015

${ }^{x i}$ DREES (2016) Comptes de la santé

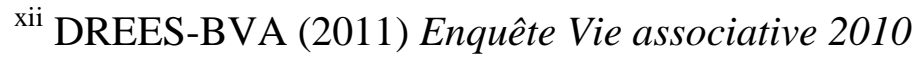


Prouteau, Lionel (2013) Le travail bénévole in Tchernonog Viviane, Le paysage associatif français. Mesures et évolution, Paris, Juris-éditions et Dalloz, p. 59-83 